\title{
The Discrepancy of Curriculum 2013 in Teaching and Learning Process Based on Permendikbud No 65 of 2013 in SD Laboratorium Undiksha
}

\author{
Ni Luh Sadewi Widyani1,*, Ign. I Wyn. Suwatra'2, I Wayan Widiana ${ }^{3}$ \\ 1 Departement of Primary School Teacher Education. Universitas Pendidikan Ganesha, Indonesia \\ 2 Departement of Primary School Teacher Education. Universitas Pendidikan Ganesha, Indonesia \\ ${ }^{3}$ Departement of Primary School Teacher Education. Universitas Pendidikan Ganesha, Indonesia
}

\begin{abstract}
This research aimed to determine how large the discrepancy between the ideal condition and the implementation of 2013 curriculum in teaching and learning process at SD Laboratorium Undiksha reviewed from the lesson plan, teaching learning process, assessment and learning outcomes, and the monitoring of learning process. This study was evaluative research which apply discrepancy model. Measurement of the program effectiveness was done by comparing the ideal conditions, based on Permendikbud No. 65 of 2013, with the real conditions on the implementation of 2013 Curriculum at SD Laboratorium Undiksha. Lesson plan, assessment process, and learning outcomes variable, were measured by the study documentation sheets. Meanwhile, the teaching and learning process variable was measured by observation sheets, and the monitoring of learning process variable was measured by questionnaire. Sample of the study consisted of 4 teachers of SD Laboratorium Undiksha. The scores form for all variables were analyzed using the Wilcoxon's signed rank test. The sign difference and score difference were calculated with a predetermined standard. The result of the analysis showed that the large of discrepancy between ideal conditions (based on Permendikbud No. 65 of 2013) and the implementation of 2013 Curriculum at SD Laboratorium Undiksha in terms of lesson plan is $17,90 \%$, teaching and learning process is $12,11 \%$, assessment and learning outcomes is $6,67 \%$, and the monitoring of learning process is $10,95 \%$. The discrepancy is generally due to the difficulty in changing the mindset of most education staff, tardiness of the books' distribution, and uneven training programs for educators.
\end{abstract}

\section{Keywords:}

Discrepancy,

Curriculum 2013,

Permendikbud No. 65 of 2013

\section{Introduction}

Curriculum is one of the important components of education. Tyler (in Chamisijatin, 2008) defined curriculum from four basic questions that should be answered in developing curriculum. Those four questions were: (1) what are the objectives that should be achieved by school?, (2) what learning experiences that are going to be implemented to achieve the goal?, (3) how learning experiences are organized effectively?, and (4) how to measure the objectives of the education that has been achieve? In the Undang-undang No 20 of 2003 which is about national educational system states that "curriculum is a set of plan and instruction of the objectives, content and learning material and also method to guide the implementation of teaching and learning process in order to achieve particular learning objectives. According to that definition, Agung (2014) stated that there are two dimensions of curriculum, such as (1) the plan and instruction of the objective, content, and learning material, (2) the teaching and learning method. Based on thst definition, it could be said that curriculum is not only document but also the teaching and learning process as the form of curriculum operasional system.

Curriculum will change continuously in order to get effective learning process through the changes of content, activities, and education that has been planned to fix. Kurniasih and Sani (2014) said that the changes can be happened because of the existence of globalization era and various issue related 
to the problems of the environment, the technology and information development, the rise of creative industry and culture, and the development of education in International level. Peraturan Pemerintah No 32 of 2013, as the change of Peraturan Pemerintah No 19 of 2005 which was about national standard, explains that the standard of national education needs to be balanced with the dynamics of development of society, local, national, and global to achieve the function and objective of the national education. Because of Peraturan Pemerintah No 32 of 2013, as the change of Peraturan Pemerintah No 19 of 2005 which was about national standard, Curriculum 2013 has been launched as the completing of Curriculum KTSP. According to Sariono (2013), curriculum is the foundation that is used by teachers, to teach the students into learning objecctives through the accumulation of various knowledge, skill, and character. Curriculum 2013 is a competency-based curriculum. Competency-based curriculum is outcomes-based curriculum so that the curriculum development is led to the competency achievement that is composed from the the standard competency of the output (Kemendikbud, 2012). The assessment which is conducted in Curriculum 2013 is authentic assessment. The authentic assessment asks the students to demonstrate what they understand including knowledge, skill, and other competency that they have so that it will be applicative. The authentic assessment teaches the students about meaningful learning (Bhakti et al., 2014).

Curriculum 2013 is the further step in developing the competency-based curriculum which has been launched in 2004 and KTSP which has been launched in 2006. Those curricula integrate the affective, cognitive and psychomotor (Prasetyo, 2014). The change of the previous curriculum on the competency of the output was shown in the improvement and balance of soft skills and hard skills including affective, cognitive and psychomotor. Curriculum 2013 was in trial process in 2013 by selecting some model school. In 2014, Curriculum 2013 had been implemented in grade 1, grade 2, grade 4 and grade 5 of elementary school, grade 7 and grade 8 of junior high school, and grade 10 and grade 11 of senior high school. Theoretically, Curriculum 2013 has good intention. However, the problem which is probably faced is the expectation does not meet the reality. Hamalik (2002) stated that the aim of curriculum program can be reached well if the program is designed clearly and applicative. Though it had ever been implemented for three semester, it was still not well. Related to its implementation, the Ministry of Education and Culture named Anies Baswedan gave his speech on Friday, $5^{\text {th }}$ of December 2014 in Kemendikbud Building Jakarta, which stated that there were some problems in the implementation of Curriculum 2013 such as the readiness of the book, assessment system, teachers' workshop, and teachers' and principal's monitoring which were not spread well so that it could be said that the implementation of Curriculum 2013 had not reach optimum result.

Confronting those problems, the schools which had just implemented Curriculum 2013 for 1 semester could stop its implementation. It was said by the Minister of Education and Culture named Anies Baswedan $5^{\text {th }}$ of December 2014. Through the letters which had been sent to the schools, it was known that the schools that had implemented Curriculum 2013 for more than three semester (schools that implemented Curriculum 2013 in the academic year 2013/2014) should still implement it. Then, those schools would become model school for other schools. However, the Ministry of Education and Culture also did not ban the schools which still implemented this curriculum at school. In line with the implementation of Curriculum 2013, the government especially the Minister of Education and Culture had launched several rules to make the implementation of Curriculum 2013 reach the standard. These rules were composed in the regulation of Minstry of Education and Culture (Permendikbud). One of the Permendikbud which explains how to implement Curriculum 2013 which is related to lesson plan, learning process, assessment of the learning process and result, and monitoring of learning process is Permendikbud No 65 of 2013. It was about the standard process of elementary and high school education.

The standard process of elementary and high school education was the criteria of planning, implementing, assessing and monitoring the learning process in the unit of elementary and high school education to achieve the standard competency of the output (Permendikbud No 65 of 2013). In that regulation, the minimum criteria in planning the learning process which consists of syllabus and lesson plan had been set. Besides, the way to implement the learning process at class and the assessment of learning process and result which should be conducted by the teacher had also been set. Permendikbu No 65 of 2013 also set the role of the supervisor and the head of education unit to monitor the learning process which consists of monitoring, supervising, reporting and following the result up.

Teachers as the updating agent has two roles. Those are understanding the changes that might happen and applying the changes in teaching and learning process at school (Hamalik, 2002). Although teachers are the source of changing agent, the teachers are not adaptive towards the demand of the changes of curriculum. The learning process which are conducted by them was mostly not suitable with the standard process of Curriculum 2013 because of the lack understanding towards the curriculum. In order to identify the objectives that has not been achieved and the causes of unreachability of the 
implementation of Curriculum 2013, the program evaluation should be conducted. Arikunto (2008:18) defined program evaluation as the effort to identify the implementation level of a policy carefully by identifying the effectivity of each component. In order to know the discrepancy of Curriculum 2013 implementation in SD Laboratorium Undiksha based on Permendikbud No 65 of 2013, a research entitled "An Analysis of Discrepancy of Curriculum 2013 in Teaching and Learning Process Based on Permendikbud No 65 of 2013 in SD Laboratorium Undiksha" was conducted. This study aimed at (1) identifying the discrepancy between the implementation of Curriculum 2013 in SD Laboratorium Undiksha and Permendikbud No 65 of 2013 if it was seen from learning preparation, (2) identifying the discrepancy between the implementation of Curriculum 2013 in SD Laboratorium Undiksha and Permendikbud No 65 of 2013 if it was seen from learning process, (3) identifying the discrepancy between the implementation of Curriculum 2013 in SD Laboratorium Undiksha and Permendikbud No 65 of 2013 if it was seen from learning assessment, (4) identifying the discrepancy between the implementation of Curriculum 2013 in SD Laboratorium Undiksha and Permendikbud No 65 of 2013 if it was seen from monitoring the learning process, and (5) identifying the obstacles found in the implementation of Curriculum 2013 based on Permendikbud No 65 of 2013 in SD Laboratorium Undiksha.

\section{Method}

This research was evaluative research because it oriented to the analysis which was based on the program evaluation approach that oriented in managing a program. This research was designed by analyzing the program discrepancy of variables of discrepancy model which were confirmed with the standard target of a program. The population of this research were all teachers of SD Laboratorium Undiksha Singaraja, Buleleng sub district, Buleleng regency in the second semester of the academic year $2014 / 2015$.

The technique of sample collection was purposive sampling which meant that the technique of sample collection should be based on the objectives of the research and particular consideration (Sugiyono, 2013). This purposive sampling technique was applied in order to make the sample represent all population or all level of classes. It was supported by Nasution (2012) who stated that purposive sampling could lead the researcher to arrange the sample so it could represent all population levels. Based on the researchers' consideration, the samples of this research were four levels which consisted of one class for each level. Actually, each level in SD Laboratorium consisted of two classes, namely class A and class B. In order to decide one class of each level, the researchers selected it randomly. After conducting the technique of sample collection, it could be concluded that the samples of this research were class $1 \mathrm{~A}$, class $2 \mathrm{~B}$, class $4 \mathrm{~B}$, and class $5 \mathrm{~A}$.

The program evaluation of Curriculum 2013 was about the discrepancy analysis of learning process through Curriculum 2013 based on Permendikbu No 65 of 2013 in SD Laboratorium Undiksha Singaraja. It was conducted by comparing the ideal condition and the real condition while the teachers were implementing the standard process. The component of learning which would be operated in this study should be suitable with the standard process which was stated in Permendikbud No 65 of 2013. The standard process consisted of four variables, such as learning preparation (P1), learning process (P2), assessment process (P3), and monitoring process (P4). The method which was applied to collect the data of learning preparation variable, assessment and learning achievement variable was documentation method by using documentation sheet. The method which was applied to collect the data of learning process variable was observation method by using the observation sheet. Moreover, the method which was applied to collect the data of monitoring the learning process was filling the questionnaire.

The instrument of data collection was composed based on the guidance that was stated in Permendikbud No 65 of 2013. In the evaluative study, the scale of measurement was Likert scale. Likert scale was used to measure the people's attitude, opinion, and perception about social phenomemna. The variables would be measured by verifying each variable into indicators and listing them into check list or objective type form. Before applying, the instrument items which had been composed based on the blueprint of Permendikbud No 65 of 2013 should be validated through content validity test. Nasution (2012) defined content validity as the validity which was decided by selecting the items which represented the whole material which would be measured. The process of instrument validation was conducted by three expert judgments. Based on the result, all instruments were confirmed as valid instruments so that it could be used to collect the research data. Then, the data was analyzed. This research used non parametric test by following the procedure of Wilcoxon test. Suciptawati (2009) stated that Wilcoxon test was non parametric test to measure the significances of comparative hypothesis of two samples. 
The Wilcoxon test aimed at identifying the real discrepancy between the standard and the implementation of Permendikbud No 65 of 2013 which was conducted by the teachers of SD Laboratorium Undiksha. The result of component analysis was analyzed in order to get the review of the Curriculum 2013 implementation which was based on Permendikbud No 65 of 2013 in SSD Laboratorium Undiksha. After reviewing, there were searching, confirming and concluding steps towards the learning process which was based on Permendikbud No 65 of 2013 by looking at the learning preparation, learning process, assessment of learning process and achievement, and monitoring the learning process. Then, the researchers conducted the accommodation of problems and obstacles which were found in the implementation of Curriculum 2013 based on Permendikbud No 65 of 2013 in SD Laboratorium Undiksha and the explanation of alternative recommendation of problem solving in implementing Curriculum 2013 based on Permendikbud No 65 of 2013 in SD Laboratorium Undiksha.

\section{Findings and Discussion}

The discrepancy analysis recapitulation of Curriculum 2013 implementation which was based on Permendikbud No 65 of 2013 including the analysis of learning preparation, learning process, assessment of learning process and achievement and monitoring the learning process in SD Laboratorium Undiksha could be seen in Table 1.

Table 1. Recapitulation of Analysis on the Discrepancy of Curriculum 2013 in SD Laboratorium Undiksha

\begin{tabular}{|c|c|c|c|c|c|c|c|c|c|c|c|c|c|c|c|c|c|}
\hline \multirow[b]{2}{*}{ Responden } & \multicolumn{17}{|c|}{ Varabel Pembelajaran Berdasarkan Permendisbud No. 65 Tainn 2013} \\
\hline & \multicolumn{4}{|c|}{$\begin{array}{c}\text { Perencanann } \\
\text { Penbelajaran (Pl) }\end{array}$} & \multicolumn{2}{|c|}{$\begin{array}{c}\text { Pehaksamaan } \\
\text { Pembelajaran (P2) }\end{array}$} & \multicolumn{4}{|c|}{$\begin{array}{l}\text { Peniaian Hasil dan } \\
\text { Proses Pembehjaran } \\
\text { (P3) }\end{array}$} & \multicolumn{3}{|c|}{$\begin{array}{l}\text { Pengawasan Proses } \\
\text { Pembelajaran (P4) }\end{array}$} & \multicolumn{4}{|c|}{ Total } \\
\hline No. Kelas & बे. & $\frac{\bar{c}}{\frac{5}{5}}$ & & 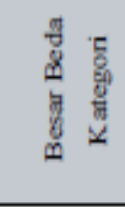 & 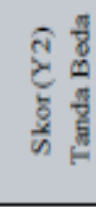 & 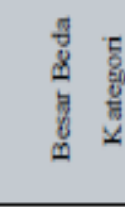 & ले & & $\frac{\frac{\pi}{8}}{\frac{8}{8}}$ & 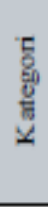 & टृ & & 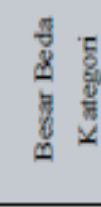 & & 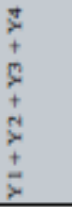 & 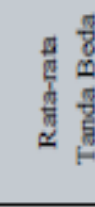 & $\begin{array}{ll}\frac{\pi}{3} & \\
8 & 0 \\
\frac{7}{8} & 0 \\
0\end{array}$ \\
\hline 1 IA & 10 & 81.48 & - & $-18.52 \mathrm{SR}$ & $87.74-$ & $-12.26 \mathrm{SK}$ & 93.33 & " & $-6.67 \mathrm{~S}$ & & 98.33 & & $-1.67 \mathrm{SR}$ & & $60.89 \mathrm{~g}$ & $90.22-$ & $-9.78 \mathrm{SK}$ \\
\hline $2 \mathbb{I B}$ & 100 & 83.63 & - & $-16.37 \mathrm{SK}$ & 90.48 - & $-9.52 \mathrm{SK}$ & 96.67 & - & $-3.33 \mathrm{~S}$ & & 82.20 & & $17.80 \mathrm{SK}$ & & 52.978 & $88.24-$ & $-11.76 \mathrm{SK}$ \\
\hline $3 \mathrm{IVB}$ & 100 & 81.93 & - & $-18.07 \mathrm{SR}$ & 87.38 - & $-12.62 \mathrm{SK}$ & 90.00 & & $10.00 \mathrm{~S}$ & & 86.82 & & $13.18 \mathrm{SK}$ & & 46.138 & $86.53-$ & $-13.47 \mathrm{SK}$ \\
\hline $4 \mathrm{VA}$ & 100 & 81.37 & - & $-18.63 \mathrm{SR}$ & 85.95 - & $-14.05 \mathrm{SK}$ & 93.33 & 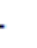 & $-6.67 \mathrm{~S}$ & & 88.86 & --1 & 11.14 SR & & 49.52 & 87.38 - & $-12.62 \mathrm{SK}$ \\
\hline Junlah & 400 & 328 & - & -71.6 & 352 & -48.45 & 373 & 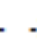 & 26.67 & & 356 & & -43.8 & & 1410 & $352-$ & -47.62 \\
\hline Rerata & 100 & 82.10 & - & $-17.90 \mathrm{SK}$ & $87.89-$ & $-12.11 \mathrm{SK}$ & 93.33 & - & $-6.67 \mathrm{~S}$ & & 89.05 & --1 & $10.95 \mathrm{SK}$ & & 352.48 & $88.09-$ & $-11.91 \mathrm{SK}$ \\
\hline
\end{tabular}

Based on the data analysis, it could be understood that the mean score of the learning preparation of planning (P1) which had been composed by the teachers of SD laboratorium Undiksha based on Permendikbud No 65 of 2013 was 82.10. Its difference with the standard was -17.90. It meant that the discrepancy was 17.90 and it belonged to very small category. It could be said that the real condition had not reached the standard or ideal condition. The mean score of learning process (P2) which was conducted by the teachers of SD Laboratorium Undiksha based on Permendikbud No 65 of 2013 was 87.89. Its difference with the standard was -12.11 . It meant that the discrepancy was $12.11 \%$ and it belonged to very small category. It could be said that the real condition had not reached the standard or ideal condition.

The mean score of the assessment of learning process and achievement (P3) which was conducted by the teachers of SD Laboratorium Undiksha based on Permendikbud No 65 of 2013 was 93.33. Its difference with the standard was -6.67. It meant that the discrepancy was $6.67 \%$ and it belonged to very small category. It could be said that the real condition had not reached the standard and ideal condition. The mean score of the monitoring process (P4) which was conducted by the teachers of SD Laboratorium Undiksha based Permendikbud No 65 of 2013 was 89.05. Its difference with the standard was -10.95 . It meant that the discrepancy was $10.95 \%$ and it belonged to very small category. It could be said that the real condition had not reached the standard and ideal condition. The mean score of the Curriculum 2013 implementation which was conducted by the teachers of SD Laboratorium Undiksha based on Permendikbud No 65 of 2013 was 88.09. Its difference with the standard was -11.91. It meant that the discrepancy was $11.91 \%$ and it belonged to very small category. It could be said that the real condition had not reached the standard or ideal condition. Based on the data analysis, it can be concluded 
that the implementation of Curriculum 2013 which was conducted by the teachers of SD laboratorium Undiksha had not completely reached the standard process of learning which was based on Permendikbud No 65 of 2013.

The mean score of discrepancy analysis of Curriculum 2013 implementation in SD Laboratorium Undiksha based on Permendikbud No 65 of 2013 was presented in the following graphic

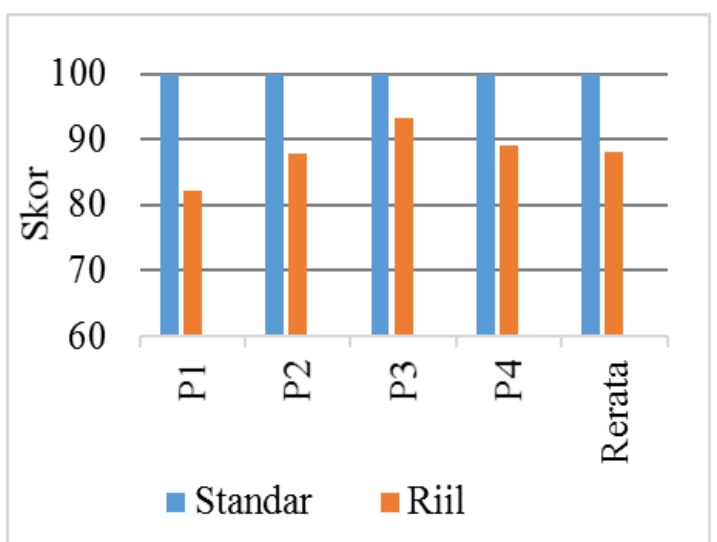

Figure 1. Graphic of Discrepancy of Curriculum Implementation Based Permendikbud No. 65 of 2013 in SD Laboratorium Undiksha

The learning preparation or planning which was based on permendikbud No 65 of 2013 consisted of syllabus, lesson plan, principles of composing lesson plan. Based on the documentation study and the data analysis, the mean score of learning preparation which was composed by the teachers of SD Laboratorium Undiksha was 82.10. Its difference with the standard was -17.90. It meant that the discrepancy between the implementation of Curriculum 2013 in SD laboratorium Undiksha and Permendikbud No 65 of 2013 if it was seen from the learning preparation was $7.91 \%$ with very small category. Based on that data analysis, it meant that generally the learning preparation which had been composed by the teachers of SD Laboratorium had reached the standard (Permendikbud No 65 of 2013). The discrepancy which was found in the components of syllabus was about the unvaried learning source (only used thematic book given by the government) and unusedness of technology. The other indicators or components were teaching scenario which were not optimal and the learning material which was not complete. The discrepancy which was found in lesson plan made by the teachers were (1) the learning objectives had not involved the audience, behaviour, condition, and degree and also had not involved the three competencies especially affective factor, (2) the teachers had only stated the brief explanation of the material without explaining the related fact, concept, principle and procedure, and (3) the teaching scenario had not represented the scientific learning.

The discrepancy of lesson plan component which was composed by the teachers consisted of the unvaried reading sources for students and the unability of teaching scenario to improve the reading habit. Besides, the lesson plan which was made by the teachers of all classes that became the sample of this study had not stated the information and communication technology. The learning process which was based on Permendikbud No 65 of 2013 consisted of the conditions of teaching and learning process. Based on the observation of learning process which was conducted by the teachers of SD Laboratorium Undiksha, the data was analyzed. The mean score of the learning process which was conducted by the teachers of SD Laboratorium Undiksha was 87.89 with the amount of difference was -12.11. It meant that the discrepancy between the Curriculum 2013 implementation in SD Laboratorium Undiksha and Permendikbud No 65 of 2013 if it was seen from the learning process was $12.11 \%$. It belonged to very small category. According to the data analysis, it generally meant that the learning process which was conducted by the teachers of SD Laboratorium Undiksha had been suitable with the standard (Permendikbud No 65 of 2013).

The indicator of the learning which had not fulfiled by the teachers yet was the syllabus explanation for the students in the beginning of semester. All teachers who became the sample of research did not explained the syllabus to the students in the beginning of semester. The indicators of learning process component which had not reached by the teachers were (1) there was no explanation about the learning objectives, (2) there was no optimal used of media and LKPD, (3) there was no feedback, (4) there was no follow up activities like group assessment, and (5) there was no material explanation for the next meeting. 
The evaluation toward the assessment of learning process and achievement which was conducted by the teachers consisted of assessment approach and learning achievement. The result of documentation study towards the assessment which was conducted by the teachers of SD Laboratorium Undiksha was analyzed. The mean score of the assessment which was conducted by the teachers of SD Laboratorium Undiksha was 93.33. Its difference with the standard was -6.67. It meant that the discrepancy between Curriculum 2013 implementation in SD Lab Undiksha and Permendikbud No 65 of 2013 if it was seen from the assessment of learning process and achievement was $6.67 \%$ wnd it belonged to very small category. According to the data, it generally meant that the assessmet of learning process and achievement which was conducted by the teachers of SD Laboratorium Undiksha had fulfilled the standard (Permendikbud No 65 of 2013).

The indicator of assessment that had not been fulfilled was the assessment should be conducted maximally by assessing the students' readiness, process, and the whole learning achievement. According to the interview data, teachers said that the assessment which was hard to be conducted was assessment of readiness and process. Meanwhile, indicators of giving follow up activities had reach the standard. It could be proven through conducting the supervision to the students who had good achievement in several lesson and the remedial to the students who had not hot the standard score. This activities were conducted in the afternoon. The discrepancy was found in class 4B and 5A who had not had counseling program for the students optimally. Through the interview, it could be found that the follow up activities were conducted through supervision and remedial. Whereas the councelling was not planned but it was conducted incidentally when the students needed to be given counselling.

The monitoring of learning process which was conducted by the head of the unit of education and the supervisor of the unit of education toward the teachers of SD Laboratorium Undiksha based on Permendikbud No 65 of 2013 consisted of monitoring, supervising, following up. According to the analysis of the questionnaire data that had been completed by the teachers of SD Laboratorium Undiksha was 89.05. Its difference with the standard was -10.95. It meant that the discrepancy between the implementation of Curriculum 2013 in SD Laboratorium Undiksha and Permendikbud No 65 of 2013 if it was seen from the monitoring of the learning process was $10.95 \%$ and it belonged to very small category. Based on that data analysis, it generally meant that the monitoring of learning process which was conducted by the head of the unit of education and the supervisor of the unit of education in SD Laboratorium Undiksha had reached the standard (Permendikbud No 65 of 2013).

After interviewing the teachers, it could be understood that the frequency of monitoring the learning process and assessment conducted by the supervisor of the unit of education was not maximal especially the monitoring which directly observed the learning process at school. The monitoring was conducted through interview or discussion. The indicator of learning supervision which had not been reached by the head of the unit of education and the supervisor of the unit of education toward the teachers of SD Laboratorium Undiksha was the supervision towards the learning preparation which was composed by the teachers and the minimal supervision for the teachers in using media and technology. Based on the interview with the teachers, it could be identified that the supervision for the teachers in using the media and learning facilities had not been maximal so that the teachers often faced some confusion in choosing the media which they wanted to use to support the learning process.

Besides that, the discrepancy was also found in the follow up activities such as (1) the lack of appreciation or achievement for the teachers who had reached the standard, and (2) the lack of opportunities for the teachers to join socialization, training or workshop which were related to the implementation of Curriculum 2013 in learning process. According to the interview with the teachers, it could be concluded that the opportunities to join the training or socialization of the implementation of Curriculum 2013 were only given to several teachers as the representatives of the school. Through this research, it was found that there was a discrepancy of the implementation of Curriculum 2013 based on Permendikbud No 65 of 2013. It showed that the teachers faced some obstacles in implementing the new policy. The obstacles found in the learning preparation were (1) the continuous curriculum changes, (2) difficulty in selecting the learning media, (3) unevenness numbers of teachers who join workshop, (4) difficult coordination with the teachers in KKG

The obstacle found in the learning process were (1) the limited books, (2) the limited materials or supporting facilities which support the lesson, (3) the delay distribution of books from the government, (4) difficulty in changing the mindset of all people at school toward the curriculum changes, especially the students of grade 4 and 5 . The obstacle found in the assessment of learning process and assessment were (1) the large numbers of students in each class which make the assessment could not be conducted maximally, (2) the complicated assessment and students' report which were different with KTSP Curriculum, (3) the difficulty in conducting the test of SBdP material because the learning process of SBdP at school was conducted by particular teachers in each class. 
Meanwhile, according to the interview about the obstacles which were faced by the head of the unit of education and the supervisor of the unit of education in monitoring the learning process which was based on Permendikbud No 65 of 2013 were (1) the difficulty in changing the teachers' mindset, and (2) the limited time of training which was given by the education institution and the unprofessional competency of the speaker.

\section{Conclusions}

Based on the data analysis and the discussion, it can be concluded that (1) the discrepancy between the implementation of Curriculum 2013 in SD Laboratorium Undiksha and Permendikbud No 65 of 2013 if it was seen from learning preparation was $17.90 \%$ and it fell into very small category, (2) the discrepancy between the implementation of Curriculum 2013 in SD Laboratorium Undiksha and Permendikbud No 65 of 2013 if it was seen from learning process was $12.11 \%$ and it fell into very small category, (3) the discrepancy between the implementation of Curriculum 2013 in SD Laboratorium Undiksha and Permendikbud No 65 of 2013 if it was seen from learning assessment was $6.67 \%$ and it fell into very small category, (4) the discrepancy between the implementation of Curriculum 2013 in SD Laboratorium Undiksha and Permendikbud No 65 of 2013 if it was seen from monitoring the learning process was $10.95 \%$ and it fell into very small category, and (5) identifying the obstacles found in the implementation of Curriculum 2013 based on Permendikbud No 65 of 2013 in SD Laboratorium Undiksha.

The obstacles found in the learning implementation of Curriculum 2013 based on Permendikbud No 65 of 2013 in SD Laboratorium Undiksha were (1) the continuous curriculum changes, (2) difficulty in selecting the learning media, (3) unevenness numbers of teachers who join workshop, (4) difficult coordination with the teachers in KKG, (5) the limited books, (6) the limited materials or supporting facilities which support the lesson, (7) the delay distribution of books from the government, (8) difficulty in changing the mindset of all people at school, (9) the large numbers of student's in each class which make the assessment could not be conducted maximally, (10) the complicated assessment and students' report which were different with KTSP Curriculum, (11) the limited time of training which was given by the education institution and the unprofessional competency of the speaker.

The result of the research which was conducted in SD Laboratorium Undiksha showed that the teachers had conducted the teaching and learning process which was based on Permendikbud No 65 of 2013 well. In order to improve the implementation of Permendikbud No 65 of 2013 in teaching by the teacher, there were many things that could be recommended, such as (1) the teachers should be adaptive towards the changes and improve their ability in implementing Curriculum 2013 like joining worknhop, KKG, and using information technology, (2) the head of the unit of education and supervisor of unit of education should monitor the learning process which was conducted by the teacher intensively and follow up the result of the monitoring like giving appreciation to the teachers who achieved the standard or giving another chance to the teachers who did not reach the standard to get further supervision and workshop, (3) the result of evaluating the learning implementation should be conducted oftenly so that the discrepancy and uncompleted component could be identified and the nonstandard implementation could be revised, (4) the government should not only have the educational academician of composing the national standard of education involve, but also the teachers as the educational practitioner, (5) the government should pay more attention on the facilities of education which are needed fast and accurately, especially the students' books which did not arrived on time, and (6) the government should conduct socialization intensively through workshop, training, seminar, competition of learning design, or other activities involving all teachers, head of unit of education, supervisor of the unit of education and related institution.

\section{References}

Agung, A. A. Gede. 2014. "Arah Penelitian Pendidikan Dasar (Ke-SD-an) Berorientasi Kurikulum 2013". Makalah disajikan dalam Seminar Akademik Jurusan PGSD. Universitas Pendidikan Ganesha, Singaraja Oktober 2014.

Arikunto, Suharsimi dan Cepi Safrudin Abdul Jabar. 2008. Evaluasi Program Pendidikan. Jakarta: Bumi Aksara.

Bhakti AS, Sentot Kusairi \& Muhardjito. 2014. Pengembangan Model Penilaian Autentik Berbasis Kurikulum 2013. HIm 1 -12.

Chamisijatin, Lise. 2008. Pengembangan Kurikulum SD. Jakarta: Departemen Pendidikan Tinggi

Hamalik, Oemar. 2002. Perencanaan Pengajaran Berdasarkan Pendekatan Sistem. Jakarta: Bumi Aksara. 
Kemendikbud Kementrian Guru dan Kebudayaan 2012. Kurikulum 2013. Jakarta: Kementerian Guru dan Kebudayaan.

Kurniasih, Imas dan Berlin Sani. 2014. Sukses Mengimplementasikan Kurikulum 2013. Jakarta: Kata Pena Nasution, S. 2012. Metode Researsh. Jakarta: Bumi Aksara .

Permendikbud Nomor 65 Tahun 2013 tentang Standar Proses Pendidikan Dasar dan Menengah.

Prasetyo, Zuhdan K. 2014. "Generasi Emas 2045 sebagai Fondasi Mewujudkan Siklus Peradaban Bangsa Melalui Implementasi Kurikulum 2013 di Sekolah Dasar". Makalah disajikan dalam Seminar Nasional Kurikulum 2013. Universitas Tanjungpura, Pontianak 16 April 2014.

Sariono. 2013. Kurikulum 2013: kurikulum generasi emas. E-Jurnal Dinas Guru Kota Surabaya, 3:1-8.

Suciptawati, Ni Luh Putu. 2009. Metode Statistika Nonparametrik. Denpasar: Udayana University Press.

Sugiyono. 2013. Metode Penelitian Pendidikan. Bandung: Alfa Beta

Undang-Undang Nomor 20 Tahun 2003 tentang Sistem Pendidikan Nasional

Undang-Undang Nomor 32 Tahun 2013 tentang Standar Nasional Pendidikan 